\title{
Effect of an artisanal fishery on the fish and urchin populations of a Kenyan coral reef
}

\author{
M. Watson, R. F. G. Ormond \\ Tropical Marine Research Unit, Biology Department, University of York, York Y01 5DD, United Kingdom
}

\begin{abstract}
An investigation of the effects of artisanal fishing on coral reef fish assemblage structure was undertaken through a comparison of fish stocks on 2 apparently identical sets of reefs, one (within the Kisite Marine National Park) on which all fishing is prohibited, and one (within the Mpunguti Marine National Reserve) on which artisanal fishing only is allowed. Replicate visual censuses of fish along $250 \times 10 \mathrm{~m}$ band transects at 6 intensive study sites demonstrated that there were large differences in population density and biomass of the principal families of commercial reef fish (Lethrinidae, Lutjanidae and Serranidae) between the unfished marine park area and the adjacent intensively fished marine reserve area, with abundances of commercial species within the park (unfished) being up to 10 or more times those in the reserve (fished). In addition, 6 species of butterflyfish (Chaetodontidae) and 2 species of triggerfish (Balistidae) were significantly more abundant on shallow and/or deep transects within the park. For most species of commercial fish, larger individuals were observed in the park than in the reserve, an effect expected from greater fishing pressure within the reserve. In contrast, smaller Cephalopholis spp. (Serranidae), 1. species of butterflyfish, and sea urchins (mostly Echinometra mathaei) were significantly more abundant on transects in the reserve. It is suggested that these increased abundances may be second order effects (mediated by reduced competition or predation) of increased fishing pressure. In particular, opposing differences in abundance of predatory triggerfishes (Balistidae) and emperors (Lethrinidae) and of sea urchins are compatible with the view that higher populations of sea urchins may sometimes occur where the densities of their predators are reduced. Overall results allow an assessment of the effect of the artisanal fishery on the fish stocks, and provide a measure of the effectiveness of protection afforded by the marine park.
\end{abstract}

KEY WORDS: Coral reefs · Fisheries · Marine parks · Reserves · Reef fish · Sea urchins

\section{INTRODUCTION}

Management of coral reef fisheries presents a particular problem since traditional single-stock approaches are impractical and inappropriate to tropical multi-species fisheries. Nevertheless, the effects of fishing on coral reef fish communities are increasingly well documented, and include effects on both abundance and size structure. Abundance is often reduced in fished populations. Alcala (1988) and Russ \& Alcala (1989) found abundance in protected areas was almost twice as high as in unprotected reefs in the Philippines. Clark et al. (1989) noted similar increases in abundance following a spear fishing ban in the Florida Keys, USA. Russ (1985), Ayling \& Ayling (1986), Buxton \& Smale (1989) and G. Gaudian, P. A. H. Medley \& R. F. G. Ormond (unpubl.) also found differences in abundance between fished and unfished areas.

Fishing causes a decrease in the average size of fish as mean age falls. Ferry \& Kohler (1987), Bohnsack et al. (1989) and Sparre et al. (1989) also note that fishing may selectively target the larger fish in a population, causing a further fall in mean size. Field studies include the work of Craik (1979) who found the average weight of fishes caught on reefs around Townsville (Australia) almost halved over 15 yr. Beinssen (1989) found Plectropomus leopardus increased in length by an average of $13 \mathrm{~cm}$ when an area of the Great Barrier Reef was protected for 3.5 yr. However, 18 mo after fishing resumed, the average length had fallen by $5 \mathrm{~cm}$. Buxton \& Smale (1989) report a near doubling in size of Petrus rupestris when a protected area was compared with an exploited region. 
Productivity of a fish population might increase under low to moderate fishing pressure as a larger proportion of the population is in a phase of rapid growth. On the other hand, reef fish may be singularly vulnerable to over-fishing. Ursin (1982) and Pauley (1979) suggest that prey stocks are often already optimally exploited by predatory species, and in these cases even limited fishing could cause a decline in productivity. Johannes (1978) also found a 'disproportionate number and biomass of predators'. Grigg et al. (1984) estimated ecotrophic efficiency of a studied reef to be 0.85 to 1.0 (i.e. at least $85 \%$ of the production of each species group is consumed directly by its predators). This should be compared with the average figure given by Ricker (1969) of 0.75 for secondary and above consumers in marine communities. Thus reef systems can easily be over-fished as exploitable annual productivity may be lower than suggested by measures of gross primary production. Natural mortality may also be high.

In this context, marine parks are increasingly being seen as a management tool in such tropical multispecies fisheries. Bohnsack (1990) lists 10 roles for parks which include the protection of spawning biomass, the capacity to act as a recruitment source for surrounding fished areas, to restock such areas through the emigration of adults from the protected area, to protect habitat, to maintain diversity and act as an insurance policy against man's mismanagement of these fragile resources. Roberts \& Polunin (1991) provide an excellent review of information pertinent to marine reserves as a management tool, with particular emphasis on the reserve as a recruitment source, and the restocking of fishing grounds through emigration.

This study details a quantitative investigation into the effects on reef fish populations of restrictions on fishing within a section of the southern Kenya coast. The area includes 2 comparable sets of reefs, (see 'Study area') one set (within the Kisite Marine National Park) currently subject to strict protection, and the other set (within the Mpunguti Marine National Reserve) open to artisanal fishing, but with the use of spear guns, poison, and the collection of shells and aquarium fish banned (Olindo \& Asava 1975).

In 1988 the biomass of the major commercial families (Lethrinidae, Serranidae and Lutjanidae) was found to be similar between reserve and park (Samoilys 1988). However, the Kenya Wildlife Service, who now manage both areas, considered that the fishing ban in the park was enforced much more effectively after 1989 . Thus, it was anticipated that quantitative surveys of comparable park and reserve areas would both allow an assessment of the effect of artisanal fisheries on the fish stocks, and provide a measure of the effectiveness of protection and of the value of the park area to fisheries management.

\section{METHODS AND STUDY AREA}

Study area. The work was undertaken during September and October 1992 in Kisite Marine National Park (KMNP) and Mpunguti Marine National Reserve (MMNR), which are near the Tanzanian border on the southernmost part of the Kenyan coast (Fig. 1). The park and reserve cover an area of $23 \mathrm{~km}^{2}$ about $5 \mathrm{~km}$ offshore of the small town of Shimoni, on the seaward side of Wasini Island. Fig. 1 shows the reefs and boundaries of reserve and park. Both were managed by the Wildlife Conservation and Management Department of the Ministry of Tourism and Wildlife until 1989, when the department was reformed as the Kenya Wildlife Service (K.W.S.).

Both the park and fishery are important to the local economy. In 1991, 32952 visitors came to the park bringing in a revenue of approximately $£ 83500$ sterling. The artisanal fishery is the only source of income for many people, and is also an important source of dietary protein. There is a potential conflict of interest between those who receive income from the park (the K.W.S. and businesses involved in the tourist industry), and the local people who may see the park as depriving them of fishing grounds, without compensating benefit.

Fishing in the Shimoni area is largely traditional, at least on the reefs. Few fishermen have outboard motors, and the most common craft is the dugout canoe, the number of fishermen in a canoe depending on its size. Next most common is the ngalawa or outrigged canoe, often with 3 fishermen. Mashuas are larger boats with sails usually used on longer distance fishing trips. Fishing gear recorded by Coppola (1982) includes gill nets, trammel nets, cast nets, beach seines (known to be destructive of reef habitat; see Bryceson et al. 1990), usio (traps built out from the shore, in line with the current) and malema traps. In the study area malema (or basket) traps are the most common gear, although gill netting was also occasionally observed, and beach seining is known to have occurred at Mpunguti until a ban in early 1994.

The reefs themselves represent a series of 4 large platforms, 3 topped by a small cay or island together with adjacent small patch reefs, formed on a shallow shelf 10 to $20 \mathrm{~m}$ deep. The reef form and coral assemblage was investigated in a parallel study (Stevenson 1993). Typically the reef flat, which is covered by up to $2 \mathrm{~m}$ of water at high tide, gives way to a reef slope descending at an angle of 45 to $60^{\circ}$ to the sea bed. The coral assemblage in both park and reserve was dominated by massive and branching species of Porites. In both areas hard coral cover was estimated to be between 40 and $60 \%$, with the variation between protected and unpro- 
tected areas appearing no greater than variation within these areas. However, at a few sites in the reserve, reef face areas up to $25 \mathrm{~m}$ diameter had low hard coral cover and showed damage characteristic of bioerosion by sea urchins (see Messiha-Hanna \& Ormond 1982, Hay 1984). Aggregations of up to 300 Diadema setosum were present at a few of these sites.
Underwater survey techniques. Underwater surveys were carried out to compare the fish communities in the reserve and in the park. A total of 6 sites were surveyed intensively; 4 were within the park (3 on Kisite reef and 1 at Mako Kokwe) and 2 in the reserve (one on Captain Hassan's reef and the other on Mpunguti Lower reef). The locations of these sites are shown in Fig. 1, detailed map. At each site, $250 \mathrm{~m}$ transect lines were laid, one at approximately $5 \mathrm{~m}$ depth and the other, parallel to the first, at $10 \mathrm{~m}$, or at the base of the coral zone if that was shallower the entire area shown in Fig. 1, detailed map, rarely exceeds $15 \mathrm{~m}$ depth). Observers swam at an approximately constant speed $\left(10 \mathrm{~m} \mathrm{~min}^{-1}\right)$ along the transect lines and censused fish within $5 \mathrm{~m}$ either side of the line. Counts were recorded on waterproof forms. Normally 5 replicate counts (minimum 3) were completed over $2 \mathrm{~d}$ for each group of fish being censused. Care was taken to stagger the counts so as to minimise disturbance of the fish. All counts were made between 08:30 $\mathrm{h}$ and 14:00 $\mathrm{h}$, because sea conditions deteriorated in the afternoon.
Fig. 1. Map of the Kenyan Coast and the boundaries of Kisite Marine National Park and Mpunguti Marine National Reserve near Shimoni. Location of the reefs and the intensive and non-intensive survey sites are marked 
The fish being studied fell into 3 groups:

(1) Lethrinidae (emperors), Lutjanidae (snappers) and Serranidae (groupers) were counted as the dominant commercial species.

(2) Chaetodontidae (butterflyfish) were censused to provide a comparison of diversity in non-commercial species between the 2 sites and as an indicator of reef health (Reese 1981, Roberts et al. 1988). All species of butterflyfish were recorded. Zanclus cornutus (family Zanclidae) was included in the count to avoid confusion with Heniochus butterflyfish.

(3) Balistidae (triggerfish), large Labridae (wrasse) and Diodontidae (pufferfish) were recorded as potential predators of large invertebrates.

Most fish were identified to species but some less common species only to genus. Those identified to species were selected so as to be easily identified by less experienced observers and comparable with previous work by Samoilys (1988) on the Kenya coast. and by Gaudian et al. (unpubl.) in work on the artisanal fishery at Zanzibar, Tanzania. In the case of the snapper most common at Kisite, it proved impossible to distinguish reliably between Lutjanus ehrenbergi and $L$. fulviflamma due to the large numbers present, hence in counts these 2 species were grouped together.

To maximise accuracy of searching and counting, each observer counted fish belonging to only one group of species which used the reef habitat in an ecologically similar way. These procedures helped to ensure accurate identification and to reduce variability in the data (Greene \& Alevizon 1989, Ormond unpubl. data). Details of technique differed for different species groups. Divers counting cryptic species actively looked for them under overhangs, behind large coral heads, etc., whereas divers censusing easily disturbed fish looked further ahead along the transect. The largest potential source of error was misidentification, since few of the observers were familiar with the fishes of the region prior to training. In the analysis, data known to be unreliable or non-standard (for example where the diver had been concentrating on training another diver, or had to cut short a dive) were excluded. For the commercial species (group 1), size was estimated, using the following categories $(\mathrm{cm}$ ) which we have found to be most easily distinguished (after training) by divers: $<20,20-29,30-49,50-74,75-99,100-130$, $>130$. Bell et al. (1985) showed that divers can produce consistent estimates of length, but often at first underestimate size by overcompensating for the $30 \%$ apparent increase in an object's size when seen under water. Calculations of fish biomass were made to be comparable with the results of a broad scale survey of the Kenya coast by Samoilys (1988). Observers, who dived in pairs, included, in addition to the authors, a team of 8 volunteers assembled under the auspices of the Reefwatch Programme. All were experienced divers, a majority being science graduates. Most had already participated in one or more similar projects, and a short training programme was provided.

In addition to the intensively surveyed sites, other non-intensive sites, both within the park and reserve and in unprotected areas, were censused more simply, with pairs of divers carrying out a single count by finning for $25 \mathrm{~min}$ (at about $10 \mathrm{~m} \mathrm{~min}^{-1}$ ) in a set direction at $10 \mathrm{~m}$ depth, then returning at $5 \mathrm{~m}$ (i.e. without laying a transect line). The positions of these sites are also shown in Fig. 1. The census sites, both intensive and non-intensive, were not always ideally placed in terms of experimental design, but were influenced by logistical and time constraints. The data from Mako Kokwe reef were not used in the main analysis due to problems locating the site which was then found to have experienced heary dynamiting in recent years (Samoilys 1988).

In addition to fish species, echinoids were also censused to check for possible second order interactions influencing their abundance. Echinoids found within $1 \mathrm{~m}$ either side of the transect were counted for 2 intensive survey sites in the reserve, and 2 in the park. Each $1 \mathrm{~m}$ wide strip was considered a separate count, and the mean abundance of urchins was calculated for reserve and park.

Biomass. Estimates of individual fish biomass were calculated so as to be directly comparable with those given in Samoilys (1988), using the equation

$$
\text { Biomass }=\text { Constant } \times \text { Length }^{\text {exponent, }}
$$

and the same sources of published data for the mass and length relationships of similar species (Loubens 1980, Wright \& Richards 1985). Average fish biomass per $1000 \mathrm{~m}^{2}$ for the families of commercially targeted fish was then calculated using a combination of individual fish biomass estimates with counts for each fish size class.

Mean abundance plots. The differences in mean abundance between reserve and park for several species are analysed below. Due to limited data, replicate counts were pooled between sites within the 2 treatments. It is acknowledged that the confidence limits may be wider than shown on the graph as the variance within sites is not separated from that between treatments. A better estimate might have been obtained using the error terms of hierarchical analysis of variance, but the lack of a normal distribution in the data precluded this approach. However, for several species, the difference in abundance between fished and unfished areas is so large there can be little doubt that there is a real effect. 


\section{RESULTS}

\section{Abundance of commercial fish species}

Lethrinidae. Counts of Monotaxis grandoculis and Lethrinus spp. were pooled within treatments (no significant difference between depths) giving a total of 16 counts from the reserve and 22 from the park at intensive survey sites. Mean abundances in the reserve and the park are shown in Fig. 2. The mean abundance of all Lethrinus spp. within the park is over 500 times higher than in the reserve. For $M$. grandoculis the numbers are much smaller, but the abundance in the park is still 5 times that in the reserve. Both differences are significant (Mann-Whitney $U$-test, $p<0.001$ and $\mathrm{p}<0.01\}$.
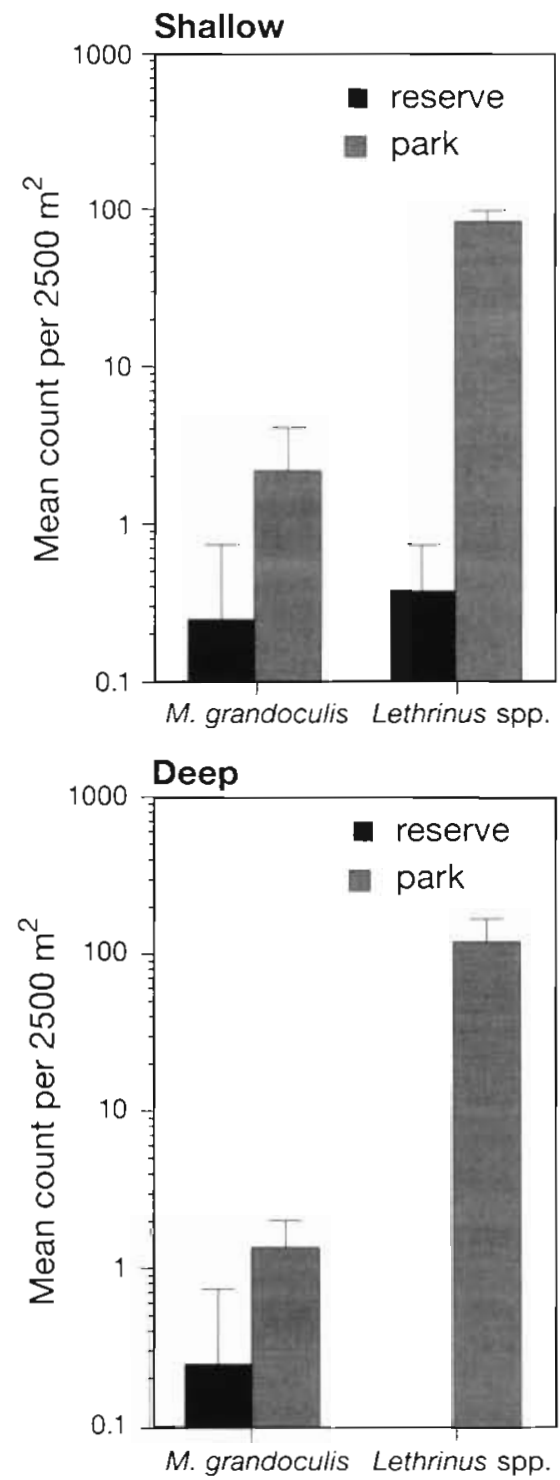
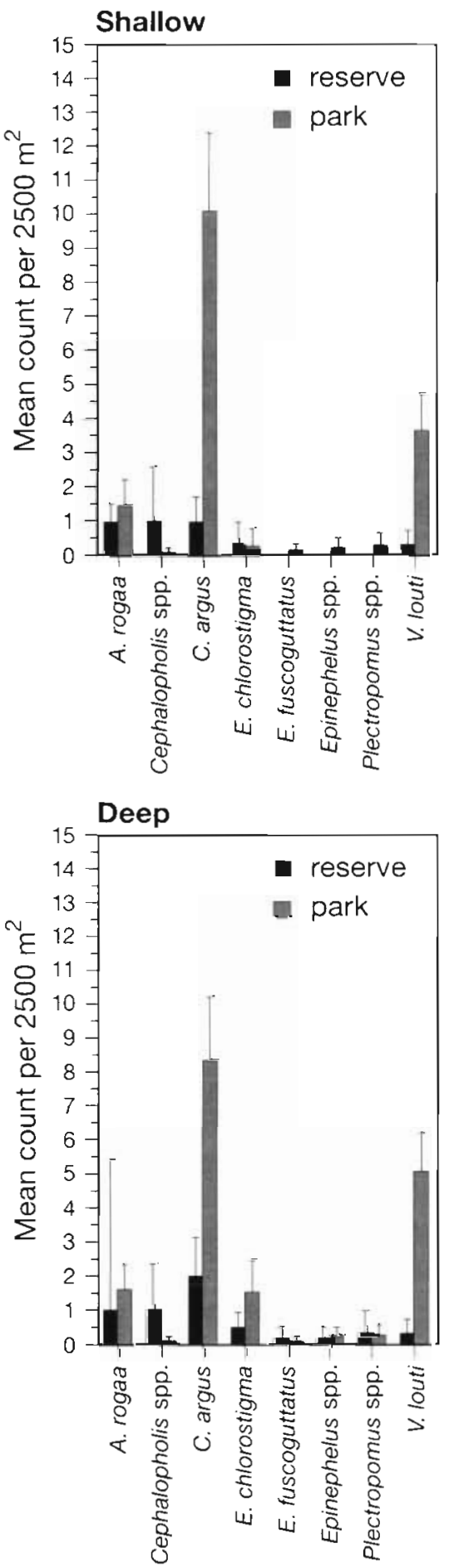

Fig. 3. Aethaloperca rogaa, Cephalopholis spp., Epinephelus spp., Plectropomus spp., Variola louti. Graphs of mean abundance for serranids at shallow and deep intensive survey sites. Error bars represent $95 \%$ confidence intervals

Fig. 2. Monotaxis grandoculis, Lethrinus spp. Graphs of mean abundance for lethrinids at shallow and deep intensive survey sites. Note the log scale. Error bars represent $95 \%$ confidence intervals 
Serranidae. There were a total of 15 counts for each species from the park and 6 from the reserve at each depth. The data from deep and shallow transects within treatments were checked for heterogeneity before pooling. Only Epinephelus chlorostigma was found to be significantly different between the 2 depths. Mean abundances are shown in Fig. 3. Three species show significantly different medians with a Mann-Whitney $U$ test; Variola louti $(\mathrm{p}<0.001)$ and Cephalopholis argus
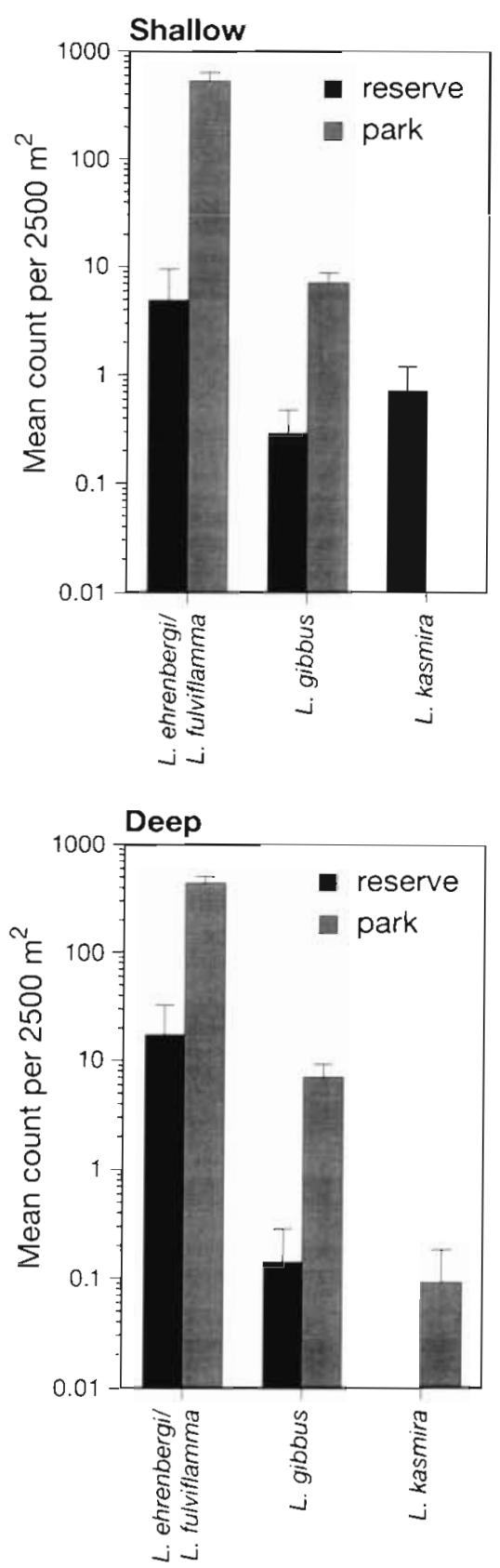

Fig. 4. Lutjanus spp. Graphs of mean abundance for lutjanids at shallow and deep intensive survey sites. Note the log scale. Error bars represent $95 \%$ confidence intervals $(p<0.001)$ are more abundant in the park and Cephalopholis spp. $(\mathrm{p}<0.05)$ is more abundant in the reserve.

Lutjanidae. For snappers, there were a total of 7 counts from the reserve and 11 from the park at each depth. Mann-Whitney $U$-tests performed on the pooled data (checked for heterogeneity) show significant differences between reserve and park for Lutjanus ehrenbergi/L. fulviflamma $(\mathrm{p}<0.001)$, L. gibbus $(\mathrm{p}<0.001)$ and Lutjanus spp. $(\mathrm{p}<0.001)$. Only L. kasmira is not significantly different between the reserve and park. The mean abundances are shown in Fig. 4.

\section{Abundance and diversity of other fish species}

Chaetodontidae. For butterflyfish there were a total of 11 counts from the reserve and 13 from the park at each depth. Depths are considered independently as it is clear from plots of mean abundance (see Fig. 5) that there is a difference between shallow and deep transects. Six species were significantly more abundant in the park than in the reserve on shallow transects (Chaetodon auriga: 1.65 vs $8.67, \mathrm{p}<0.01$; C. melannotus: 1.3 vs $5.0, \mathrm{p}<0.04 ;$ C. trifasciatus: 9.8 vs $22, \mathrm{p}<0.001 ; C$. falcula: 0.63 vs $2.17, p<0.05$; C. unimaculatus: 0.10 vs 5.25, p < 0.001; and C. guttatusimus: 3.84 vs $9.28, \mathrm{p}<$ 0.04 ) and 1 species on deep transects ( $C$. auriga: 0.8 vs $6.2, \mathrm{p}<0.001$ ). In addition, C. trifascialis ( 1.69 vs 0.08 , $\mathrm{p}<0.002)$ was significantly more abundant on deep transects in the reserve than in the park. For a few other species it is interesting to note that though no fish were seen in the park, some were observed in the reserve. These species included Heniochus monoceros and Hemitaurichthys zoster on shallow transects and Chaetodon vagabundus, Forcipiger longirostris, Heniochus monoceros, C. madakaskariensis and Hemitaurichthys zoster on deep transects.

Ranked mean abundance of butterflyfishes was plotted against species sequence (Fig. 6). Particularly at shallow transects, the curves for the 2 treatments appear to separate out. Shannon diversity indices were calculated for each of the counts of butterflyfish in the reserve and park area (Table 1) to investigate any potential difference in butterflyfish diversity between park and reserve. Since it was suspected that there is a difference between depths, the shallow and deep transects were analysed separately. Hierarchical analysis of variance was performed, but failed to detect a significant difference for either depth.

Balistidae. For triggerfish there were a total of 11 counts from the reserve, and 17 from the park at both shallow and deep transects. The data from the deep and shallow transects were treated separately as mean abundances appeared to be different at different depths (see Fig. 7). It was notable that no large triggerfish spe- 

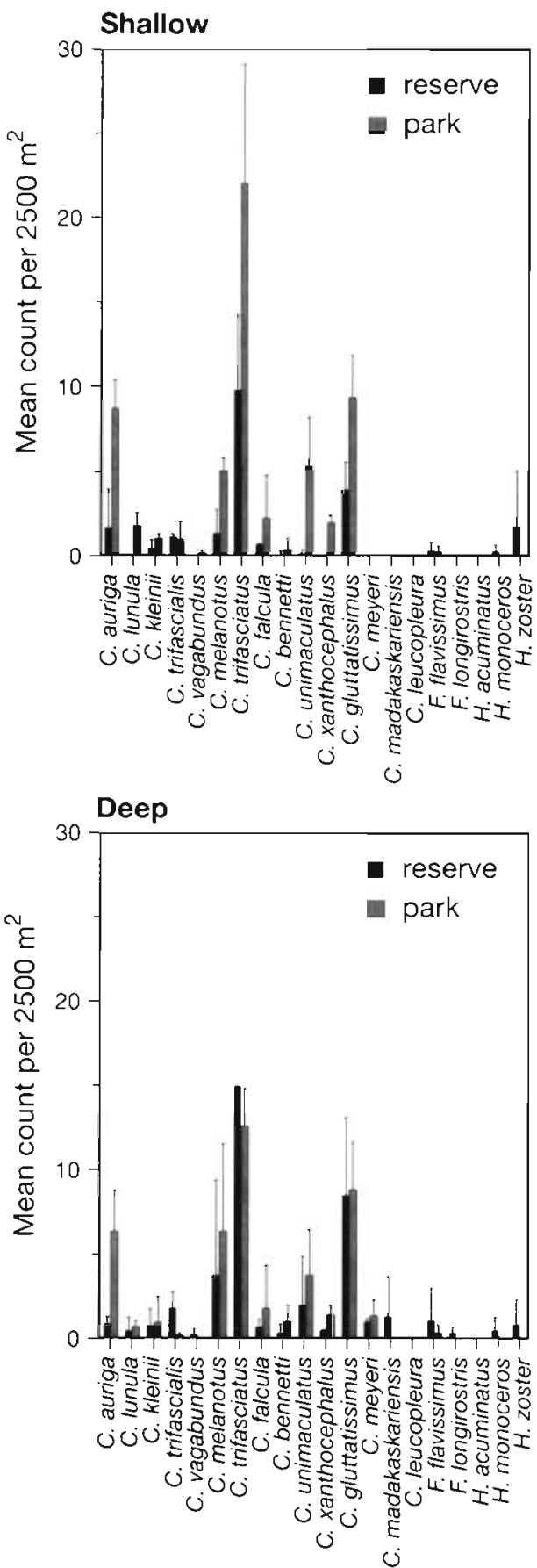

Fig. 5. Chaetodon spp., Forcipiger spp., Heniochus spp. Hemitaurichthys zoster. Graphs of mean abundance for butterflyfish at shallow and deep intensive survey sites. Error bars represent $95 \%$ confidence intervals

cies (Balistoides viridescens, Pseudobalistes fuscus and $P$. flavimarginatus) were recorded on counts in the reserve, although individuals of each of these species were seen in the park (a Mann-Whitney $U$-test could not be calculated as all the values at one set of transects being compared were zero. The overall low numbers of
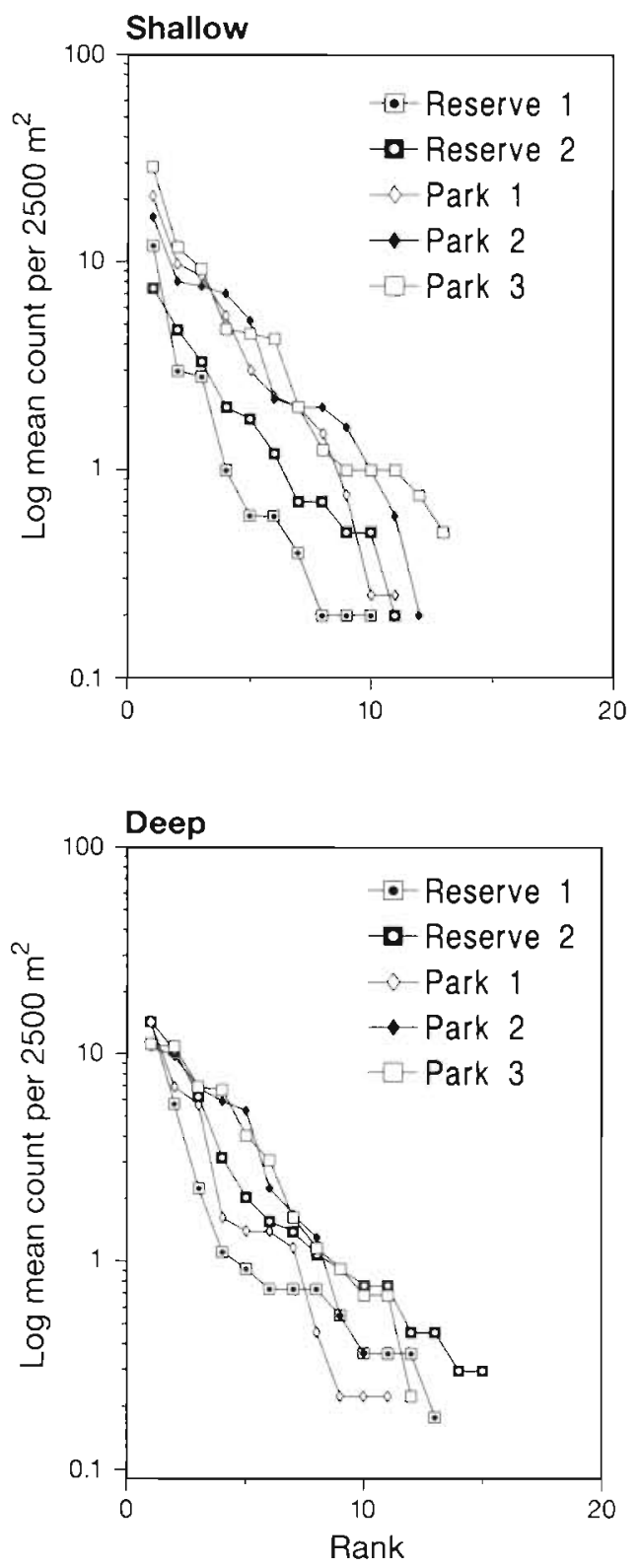

Fig. 6. Plots showing ranked mean abundance of butterflyfish against species sequence for each intensive survey site, shallow and deep transects

fish seen in any transect also made it difficult to apply an alternative statistical test, e.g. there were too few individuals seen for a chi-squared test to be carried out on the expected distribution of the fish between reserve and park). For other species where a Mann-Whitney $U$ test shows a significant difference (Balistoides undulatus, shallow transect; Sufflamen chrysopterus, deep transects) the higher median was also from the park. Also, the difference for $B$. undulatus on deep transects was almost significant $(p=0.054)$, and again the higher value was from the park. 
Table 1. Shannon diversity indices (ranked in descending order) for butterflyfish in reserve and park at shallow and deep transect sites. A 1-way analysis of variance was carried

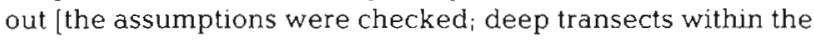
reserve could not be pooled due to heterogeneity, the diversity indices for each depth and treatment are approximately normal and the variances are homoscedastic $\left(F_{\max }=1.77\right.$, $\mathrm{df}=4,11$, not significant)]. Diversity was significantly different at reserve and park shallow transects $(p=0.016)$, but not significantly different for deep transects (Capt. Hassan and park $\mathrm{p}=0.331$, Mpunguti and park $\mathrm{p}=0.124$ )

\begin{tabular}{|cccc|}
\hline \multicolumn{2}{|c}{ Reserve } & \multicolumn{2}{c|}{ Park } \\
Shallow & Deep & Shallow & Deep \\
\hline 1.72 & 2.03 & 2.13 & 2.07 \\
1.64 & 1.83 & 2.08 & 1.95 \\
1.62 & 1.75 & 1.93 & 1.90 \\
1.58 & 1.74 & 1.83 & 1.87 \\
1.55 & 1.73 & 1.75 & 1.79 \\
1.52 & 1.73 & 1.74 & 1.70 \\
1.39 & 1.54 & 1.69 & 1.69 \\
1.35 & 1.53 & 1.68 & 1.63 \\
1.14 & 1.42 & 1.61 & 1.54 \\
0.96 & 1.34 & 1.45 & 1.47 \\
0.64 & 1.13 & 1.39 & 1.40 \\
& & 1.39 & 1.25 \\
& & 1.31 & 1.19 \\
\hline
\end{tabular}

\section{Cluster analysis of sites}

A cluster analysis was carried out on the transect sites using the counts of all species of fish as variables. For each site, shallow and deep transects were entered separately. Fig. 8 shows a major separation between the park and other sites. The 2 transects (shallow and deep) at Bait Reef, located outside both park and reserve (see Fig. 1), do not separate out from the reserve transects; a larger number of control sites (located outside park and reserve) with more reliable data would have given greater confidence in the assertion that the difference between park and reserve is due only to fishing, and not other factors such as habitat quality. Mako Kokwe, although within the boundaries of the park, clusters with the reserve sites, which we attribute to extensive dynamite damage.

\section{Abundance of sea urchins}

Fig. 9 shows urchin abundance in the reserve and park at deep and shallow intensive survey sites. It is clear that there are significantly more urchins in the reserve than the park. When the median counts of Echinometra mathaei were compared with a Mann-Whitney $U$-test (both depths combined), the result was significant at a level of 0.001 .

\section{Length and biomass of commercial fish species}

Length frequency as estimated from the survey work. Fig. 10 shows, for each commercial species, plots of the mean abundance in different size classes for reserve and park. In all cases except shallow Cephalopholis spp. larger individuals were found in
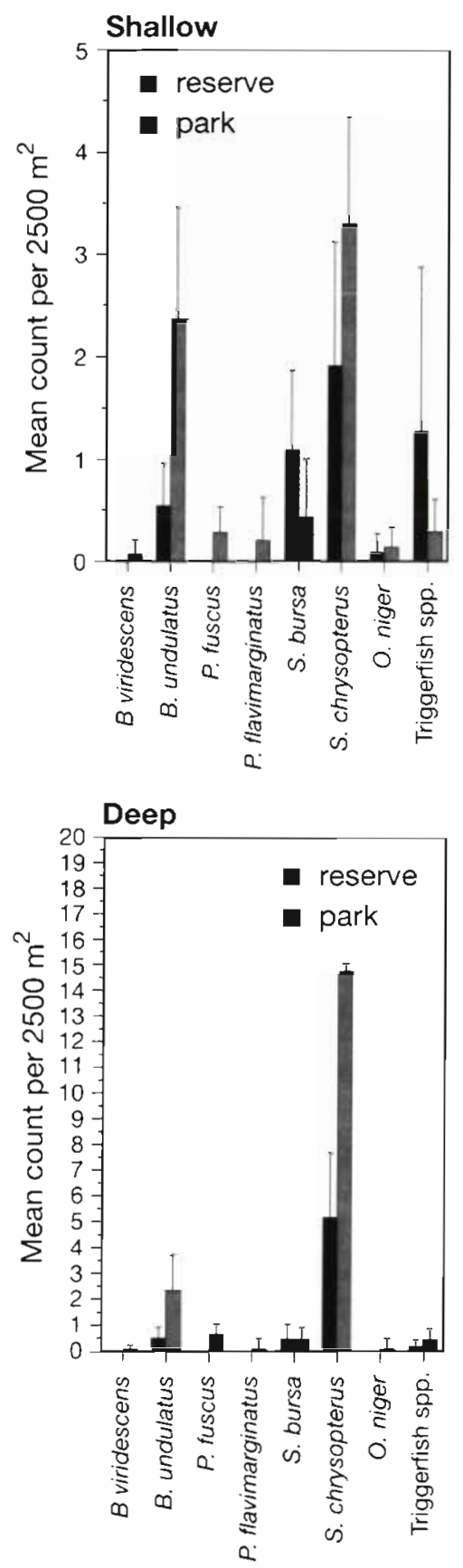

Fig. 7. Balistoides spp., Pseudobalistes spp., Sufflamen chrysopterus, Odonus niger. Graphs of mean abundance for balistids at shallow and deep intensive survey sites. Error bars represent $95 \%$ confidence intervals 


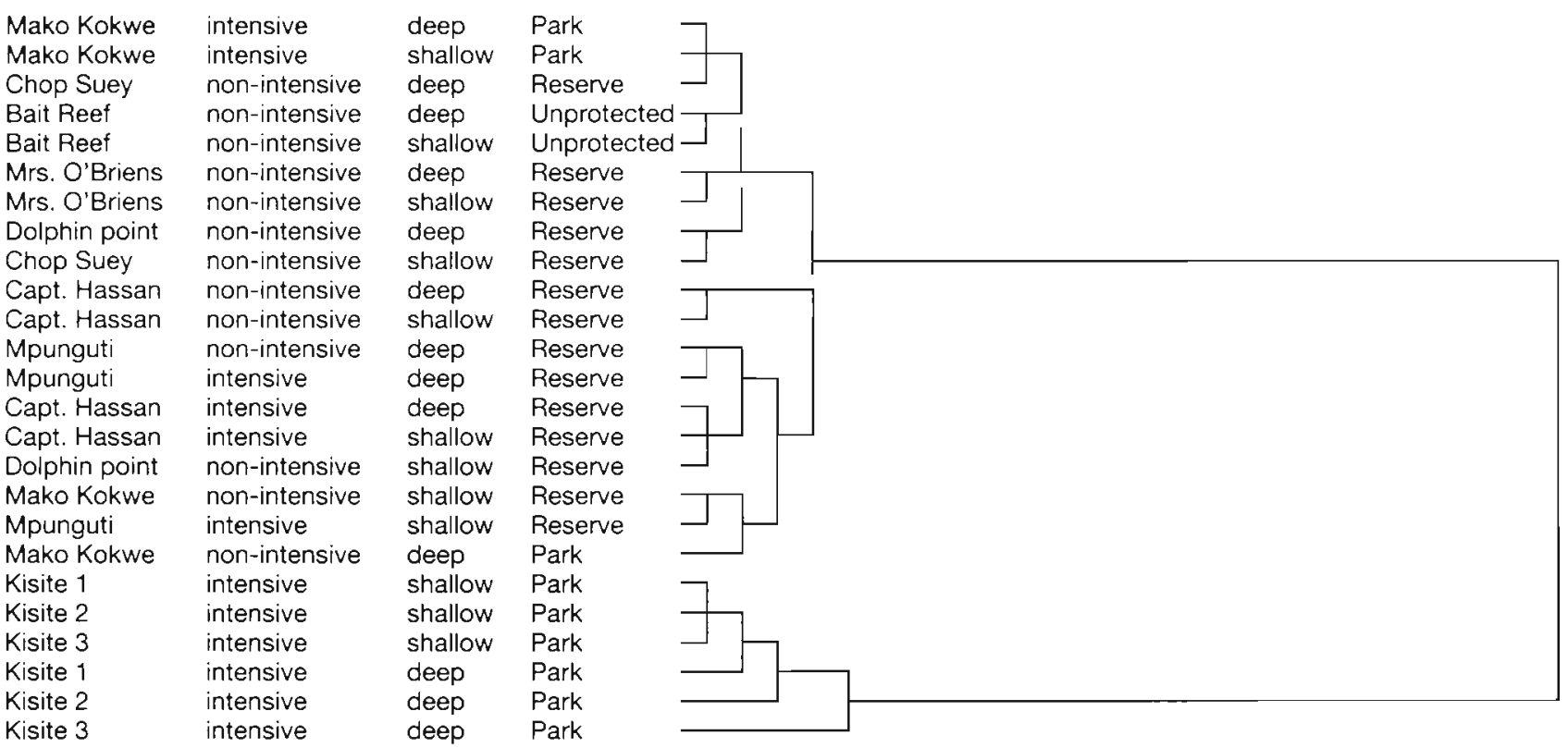

Fig. 8. Cluster analysis of all transects using all fish counts as variables. The analysis was carried out in SPSS using the chisquared dissimilarity measure for counts based on observed and expected frequencies, and the Ward's cluster method which clusters groups leading to the smallest increase in the overall sum of the squared within-cluster distances

the park than the reserve. For most species smaller individuals also appear to be more abundant in the park than in the reserve.

Biomass of commercial species in the reserve and park. Biomass of commercial species was calculated using the equation

$$
\text { Biomass }=\text { Constant } \times \text { Length }{ }^{\text {exponent }}
$$

taking the length as the mid-point of the size class, and using the values for the constant and exponent as published by Loubens (1980) and Wright \& Richards (1985), and as also used by Samoilys (1988).

From counts (shallow and deep transects pooled, all size classes) of all species within the families Lethrinidae, Lutjanidae and Serranidae, total biomass per $1000 \mathrm{~m}^{2}$ was calculated. The mean values were taken for each treatment. Fig. 11a, b shows comparisons between reserve and park for 1988 (data
Fig. 9. Echinometra mathaei, Diadema setosum, Lytechinus variegatus, Acanthaster planci. Graphs of mean abundance of urchins in the reserve and park at shallow and deep intensive survey sites. Error bars represent $95 \%$ confidence intervals
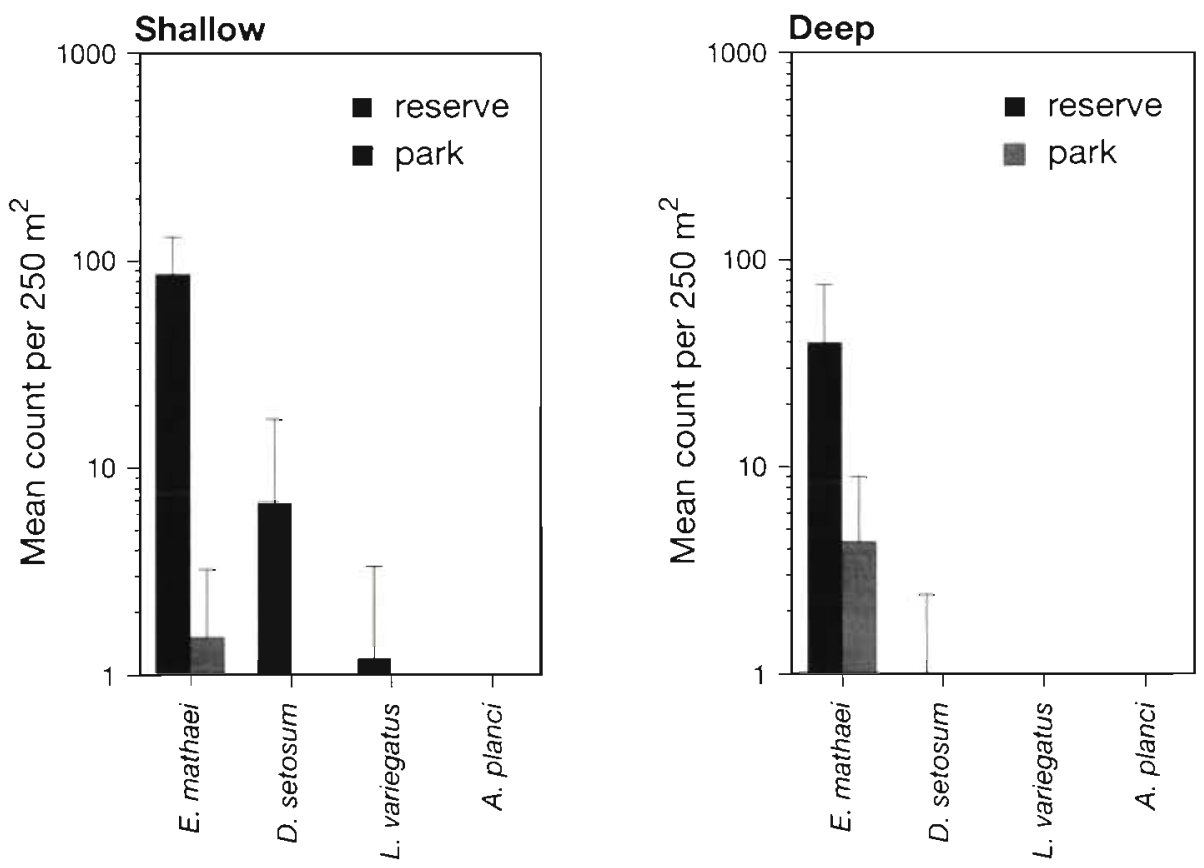
Shallow

L. ehrenbergi/L. fulviflamma

Deep
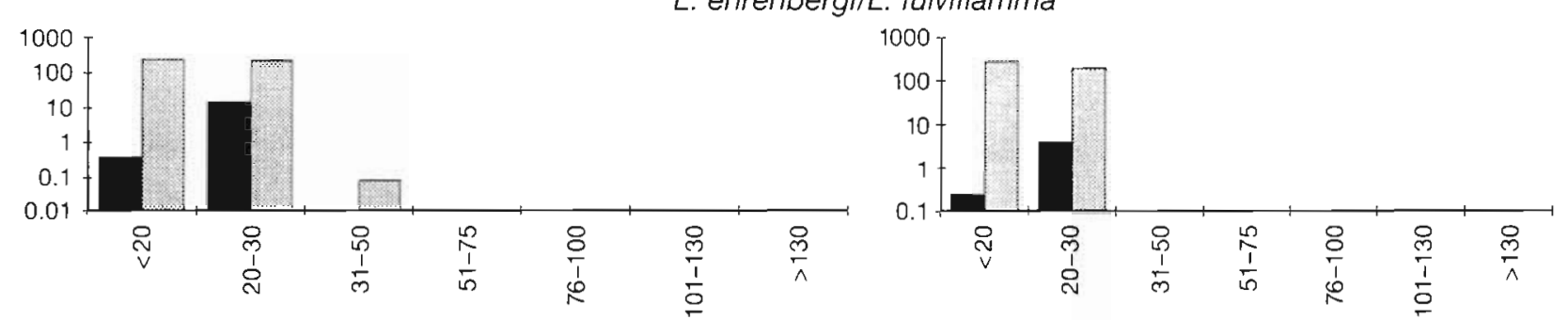

Cephalopholis spp.
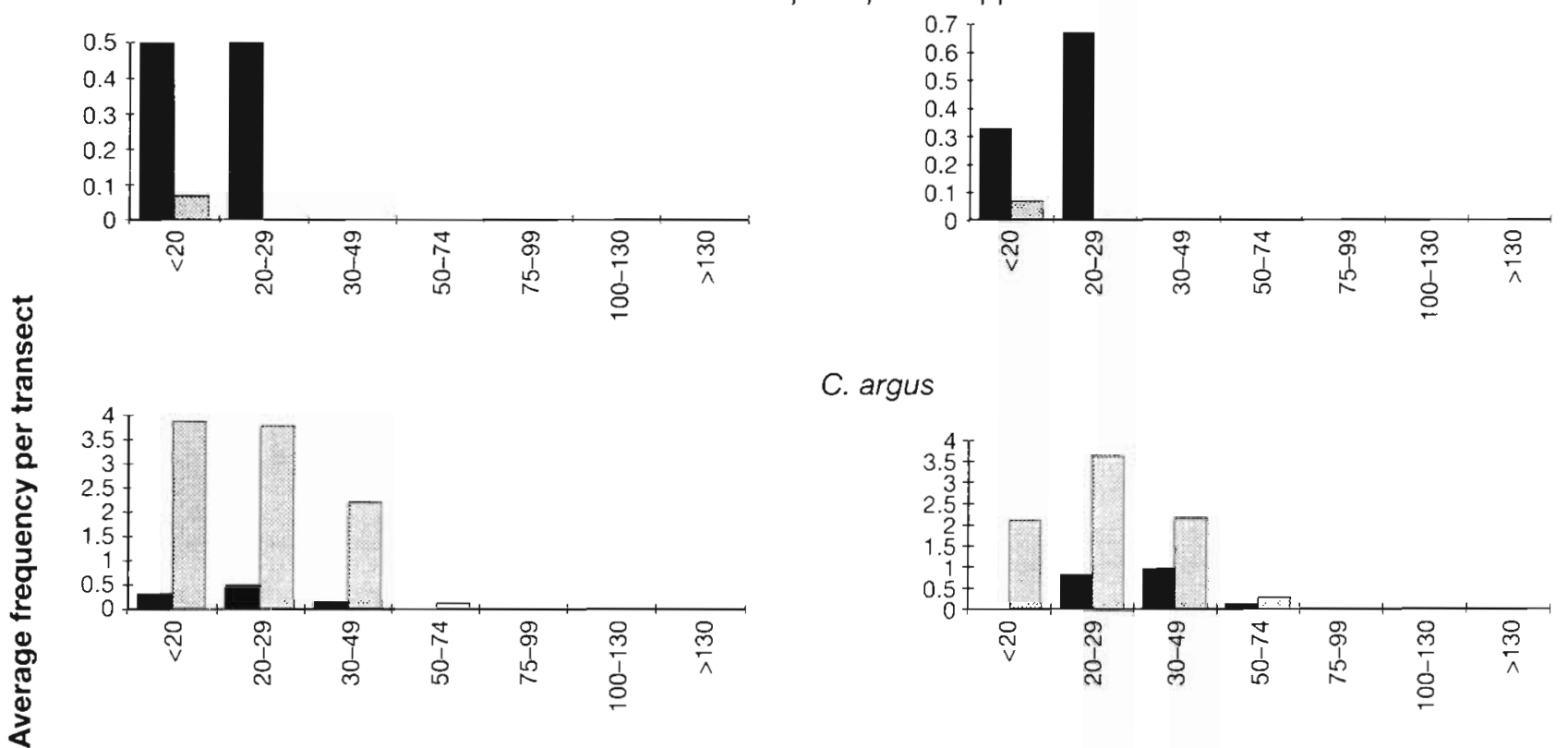

\section{C. argus}
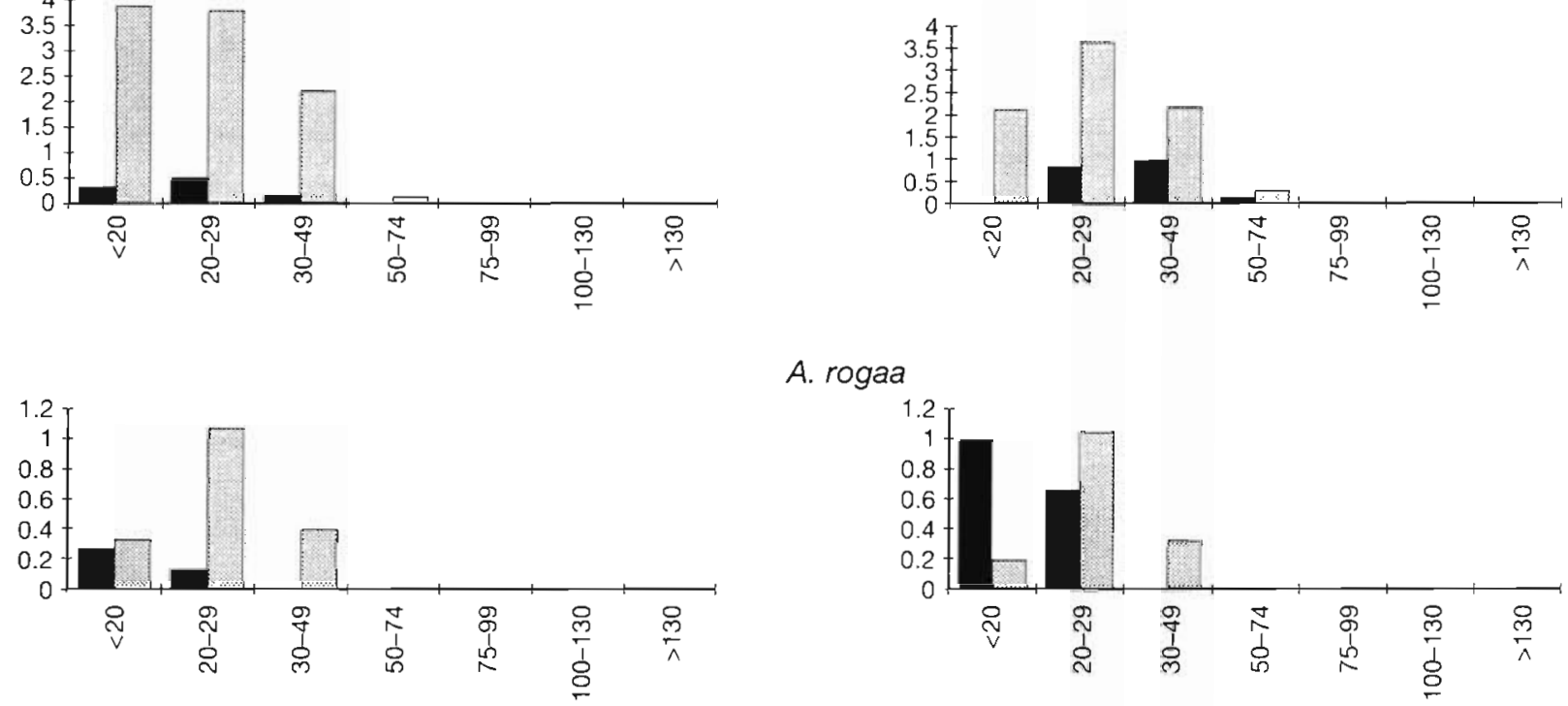

A. rogaa

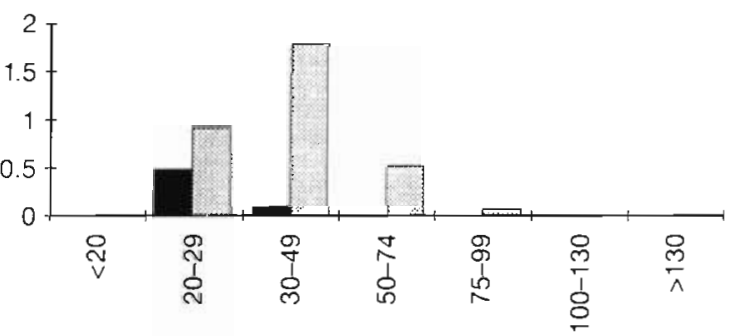

V. louti
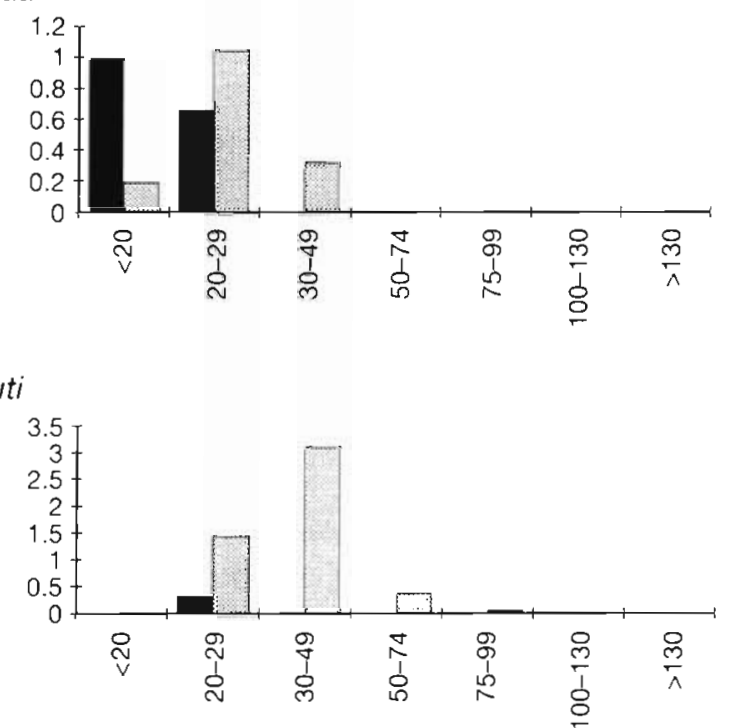

Reserve

T. Park

Size class $(\mathrm{cm})$

Fig. 10. Lutjanus spp., Cephalopholis spp., Aethaloperca rogaa, Variola louti. Mean abundance in different size classes for selected commercial species in the reserve and park 

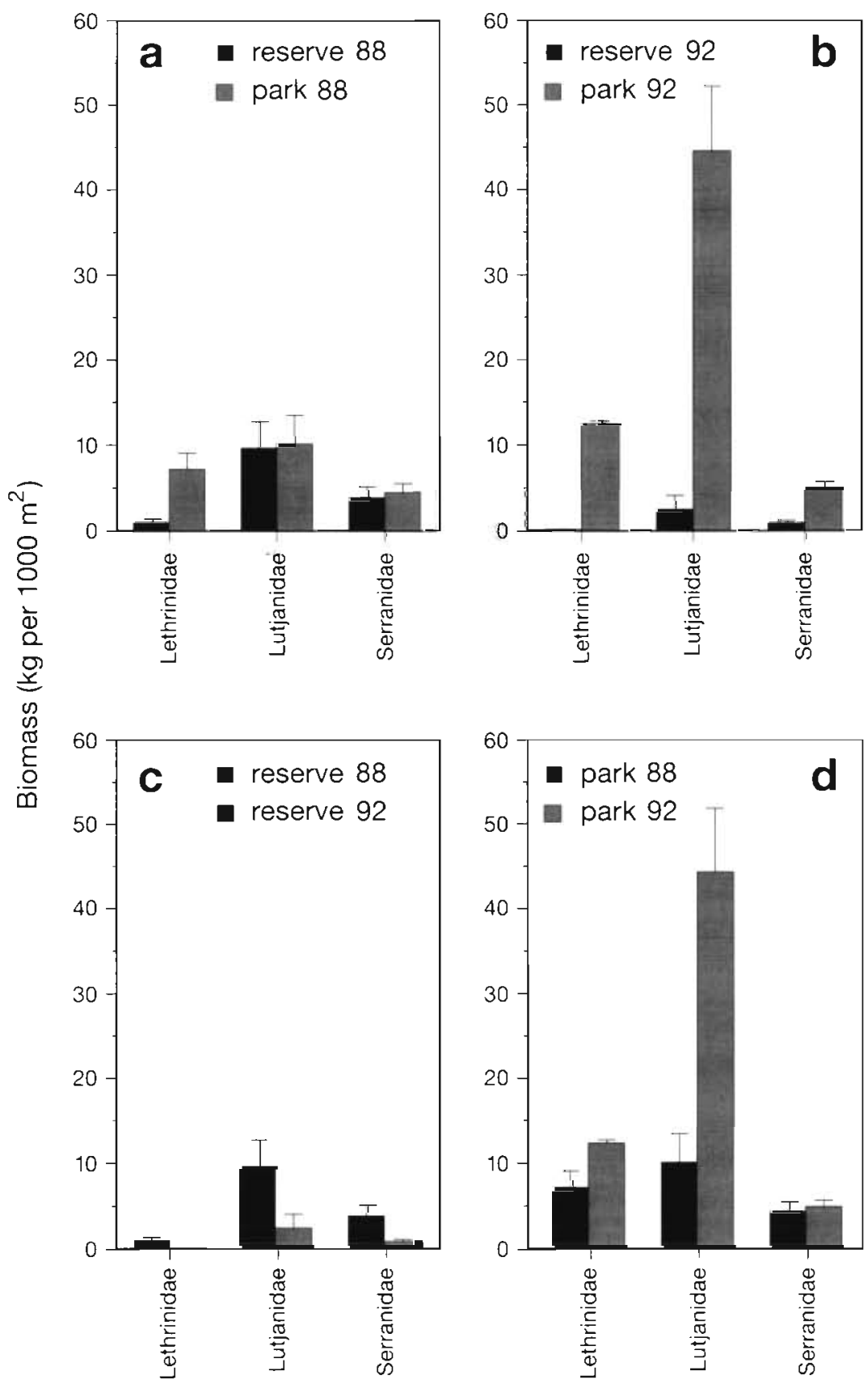

Fig. 11. Comparison of the biomass in the reserve and park in (a) 1988 and (b) 1992, and comparison of the biomass in 1988 and 1992 in (c) the reserve and (d) the park. Error bars represent standard error

from Samoilys 1988) and 1992 (the present study). It is clear that the biomass of both Lethrinidae and Lutjanidae has fallen in the reserve and risen in the park. This difference was not significant for Serranidae. As shown in Fig. 11c, d in contrast to the present (1992) data, biomass appeared fairly similar between reserve and park in 1988, assuming Samoilys' methodology to be comparable.

\section{DISCUSSION}

Of 51 species censused, 15 species were significantly more abundant in the park than in the reserve. These were: Monotaxis grandoculis, Lethrinus spp., Cephalopholis argus, Variola louti, Balistoides undulatus (shallow transects), Sufflamen chrysopterus (deep transects), Lutjanus ehrenbergi/L. fulviflamma, L. gibbus, Lutjanus spp., Chaetodon auriga, $C$. melannotus (shallow transects), $C$. trifasciatus (shallow transects), C. falcula (shallow transects), C. unimaculatus (shallow transects) and C. gluttatissimus (shallow transects). By contrast, significantly more $C$. trifacialis (deep transect) and Cephalopholis spp. were found in the reserve than in the park. The difference in abundance of the emperors and snappers between the reserve and park was especially noticeable. At Kisite the enormous shoals of snapper made counting difficult. The large standard errors on these counts probably reveal variation in divers' methods for estimation of such numbers, as well as variation due to shoals continually crossing and probably re-crossing the transect area.

While the present findings would be anticipated if the park were serving its function of protecting commercial species, such large differences in abundance have not often been demonstrated (but see 'Introduction'). Failure to record a difference in abundance with treatment could indicate that mortality is not fisheries dependent or that fisheries restrictions are not being adequately enforced (see below). In addition, although the visual census method is widely used, some problems have been documented (e.g. Thresher \& Gunn 1986). Sale \& Sharp (1983) demonstrate that visual censuses often underestimate density, and that this error increases with transect width despite the fact that precision is not impaired at greater widths. This effect varies with species, depending on their behaviour. However Brock (1982), while noting that visual censuses may underestimate cryptic and abundant species, considers that they provide a reasonable sam- 
pling technique for most other resident coral reef fishes. Dividing species into small groups rather than counting all species simultaneously has also been shown to increase accuracy (Greene \& Alevizon 1989, Ormond unpubl. data). While problems in deciding the best width of band for visual counts of fish are recognised, our experience has indicated that a $10 \mathrm{~m}$ band is an acceptable compromise, considering limitations of time and resources, and the behaviour of the different species being counted.

Differences in biomass of commercial species in the reserve and park were detected based on underwater length estimates for comparison with the data in Samoilys's (1988) report. Samoilys's data may be better suited to biomass calculations than the present data since discrimination of smaller size classes was attempted $(5 \mathrm{~cm}$ for Lethrinidae and Lutjanidae, and $1 \mathrm{~cm}$ for Serranidae). In addition more species were counted individually, presumably giving more accuracy. However, a broad comparison is still valuable.

The increased biomass in the park by comparison with the reserve since 1988 is very likely due to improved protective management, believed to have followed the park administration changing in 1989 from the Wildlife Conservation and Management Department of the Ministry of Tourism and Wildlife to the Kenyan Wildlife Service. A better enforcement of the fishing ban within the park would not only have allowed the populations of commercial fish there to recover, but have increased fishing pressure in the reserve. Even now however, it is difficult to ascertain how well the fishing ban in the park is enforced. On one occasion during survey work a ngalawa, registered in Vanga, was caught hand-lining near Mako Kokwe. The fishermen said they had strayed into the park by accident. Originally the borders were buoyed, but when the markers were continually stolen this was stopped. The rangers were uncertain when asked how often the park was violated, and different people gave different figures from none within the last 3 mo (this shortly after the above incident) to a tacit admission of a few offences every so often. However, it does seem that the park is at present fairly well protected.

Fisheries statistics (Shimoni Fisheries Department, Watson \& Ormond unpubl.) show for all fish families relatively high and stable catches between 1980 and about 1985, followed by a sharp decline until 1988; this is followed by a marked recovery over the period to 1992. This picture can be reconciled with the observed differences between fish biomass in the park and the reserve in 1988 and 1992 if the catches recorded until 1988 included many fish taken illegally from an inadequately protected park. Thus despite a fall in the reserve biomass and an apparent increase in catch since 1989 it is not necessary to assume that fishing pressure has increased overall. Instead, the fall in catch may well show overexploitation halted when enforcement of the fishing ban in the park was improved, while at the same time exploitation of the reserve will have increased, leading to a fall in biomass. It is possible that the harder fishing of the reserve while fully protecting the park is a more productive system. It may encourage adult fish to migrate into the reserve from the park and thus enter the fishery. However, Roberts \& Polunin (1991) suggest that 'any significant enhancement of fisheries by immigration can be expected to be fairly localised (i.e. $<1 \mathrm{~km}$ )'. They comment that hard data on the effect of emigration from parks to adjacent fisheries is scarce. However, studies by Alcala (1988) and Alcala \& Russ (1990) provide evidence for emigration, reporting a fall in yield of $54 \%$ in the fishery associated with the Sumilion Island Reserve in the Philippines when the protection of the reserve broke down. It should be noted that the most important species in this case were surgeon fish and fusiliers, both very mobile (Alcala 1988). The shortest distance between Kisite reef and Mpunguti Upper reef is approximately $1.7 \mathrm{~km}$. However this is probably within the range of most commercial fish; some species of snapper have been known to travel up to $18 \mathrm{~km}$, and the potential for long distance movements of groupers is demonstrated by migration to mass spawning grounds in some species (Shapiro 1987).

The number of control sites (i.e. sites outside the protection of either the reserve or the park) were limited by the constraints of time, and a lack of suitable reefs. For the one control site (outside park and reserve) that was surveyed (Bait Reef) both the shallow and deep transects group with the reserve sites in the cluster analysis. This suggests the difference in abundance of commercial fish between park and reserve is associated with the difference in fishing pressure, and not with the level of protection from other impacts. More control sites would have lent confidence to this result. However some uncertainties would have remained since Kisite was presumably an area rich in species and abundance of fish when it was chosen as a park. Moreover, originally the whole area was gazetted, but the boundaries were later redefined to alleviate the subsequent hardship to fishermen; Mpunguti may therefore be tacitly acknowledged as a less important site. Thus the possibility that the difference in fish biomass between park and reserve is due to higher quality habitat at Kisite is difficult to eliminate completely.

The data on butterflyfish are relevant to this question since Reese (1981) and Roberts \& Ormond (1988) suggest that butterflyfish may act as indicators of coral reef health. The plots of butterflyfish ranked mean abundance against species sequence (Fig. 6) at first 
suggested a difference in diversity between protection level; all the plots are approximately log normal, but shallow transects within the park appear to generate a flatter curve indicating an overall higher mean abundance, suggesting increased species diversity of butterflyfish. However, a hierarchical analysis of variance failed to detect any significant difference in diversity between protection level. Thus, the butterflyfish data are not incompatable with the assertion that the reefs in the 2 treatments are comparable, strengthening interpretations which assume that fishing alone has caused differences between treatments. At the same time, the evidence (Fig. 10) that smaller (as well as larger) individuals of commercial species are more abundant in the park than in the reserve is not necessarily evidence that the park reefs provide qualitatively different habitat than those in the reserve, since the main gear types in use caught smaller as well as large fish.

The decreased abundance of some butterflyfish and increased abundance of Cephalopholis spp. are strong candidates for second-order effects of fishing on fish community structure. Comparable effects have been reported in several other studies. Koslow et al. (1988) studied Jamaican reefs and found evidence for changes in relative abundance in a multi-species trap fishery where fishing pressure had increased, compared to a control site where little change was seen. Lock (1986) observed reefs in Papua New Guinea going, as exploitation levels rose, through 3 distinct phases characterised first by large predatory fish and large herbivores, then small predatory snappers, and finally domination by small herbivourous fish such as siganids. Goeden (1982) identified the carnivore Plectropomus leopardus as a keystone predator in his study of the Great Barrier Reef. P. leopardus made up more than half the predator community biomass in this case, and plectropomids accounted for approximately $30 \%$ of the demersal reef catch. When $P$. leopardus declined in abundance, considerable changes occurred in the community, even in fish rarely taken by fishermen. Goeden suggests that knowledge of the level of flux within the community generated by different fishing pressures could be used to set an acceptable exploitation level. Polovina (1984) found in the ECOPATH model of the French Frigate Shoals that fishing piscivores could increase sustainable yields as the amount of internal predation was reduced. In contrast, Russ \& Alcala (1989) note that removal of the top predator in a system will not necessarily lead to an increase in the prey species if many of the reef fish are generalist opportunistic carnivores; a decrease in abundance of one predator simply makes prey species more likely to be taken by other generalist carnivores.
A further second-order effect of fishing may result from an interaction of urchins and their main fish predators. McClanahan \& Muthiga (1988), based on studies in Kenya, suggest that removal of urchin predators by fishing leads to the 'ecological release' of the subsequently underutilised urchin species, and identify Echinometra mathaei as the top competitor in the urchin guild of Kenyan coral lagoons. In a similar way, Ormond et al. (1991) have linked fishing with outbreaks of crown-of-thorns starfish Acanthaster planci. The present data show there is a considerable and significant difference in urchin abundance between reserve and park. This is in contrast to the work of Samoilys (1988) who found no difference in urchin abundance in superficial assessments of these and other reefs. Samoilys also found no difference between Diani Beach and Malindi Marine National Park which were assessed quantitatively.

Further work by McClanahan \& Shafir (1990) has linked urchin density with triggerfish abundance, finding that triggerfish density was significantly negatively correlated with total sea urchin density, and positively correlated with predation rates of urchins. Similarly Ormond \& Campbell (1971) identified large triggerfish as key predators of Acanthaster planci in the Red Sea. The present findings at Kisite show Balistoides undulatus has a significantly greater abundance in the park at shallow survey sites, and Sufflamen chrysopterus a significantly greater abundance at deep sites. In addition, large triggerfish were only observed in the park, and not in the reserve. Besides triggerfish, lethrinids and lutjanids are also predators of small and juvenile urchins (Randall \& Bishop 1967, Ormond et al. 1991) and these species were also more abundant in unfished than fished areas. Thus it may be that fishing in the reserve has led indirectly to some deterioration of the habitat, if increased bioerosion by urchins has occured following ecological release as their natural predators are removed (Messiha-Hanna \& Ormond 1982, Hay 1984, McClanahan \& Muthiga 1988. McClanahan \& Shafir 1990, McClanahan et al. 1992).

The results of the present study indicate that high fishing mortality can influence the abundance of fished and non-fished species. However, as acknowledged by Russ \& Alcala (1989), if communities are recruitment limited and recruitment is variable, the effect of fishing on a reef will be difficult to detect. The effect of fishing may be influenced both directly and indirectly by the supply of plankton from other reef systems. Williams \& Hatcher (1983) and Russ (1984) note the frequent domination of planktivores in terms of both numbers and biomass, especially on the windward side of reefs, supporting the idea that population levels may be dependent on inputs of plankton from other areas. Munro \& Williams (1985) relate the high abundance of 
planktivores on Indo-Pacific reefs to a high potential productivity. By contrast, and with special relevance to the present study, Samoilys (1988) notes a 17 -fold difference between the highest abundance of fish on Kenyan reefs and that on Philippine reefs and attributes the difference principally to fewer planktivores. This she suggests may mean that the buffering effect of abundant plankton does not operate in Kenya, so that fishing may have a greater effect on fish populations there than in some other coral reef regions.

Acknowledgements. Special thanks are due to all members of the Kisite Marine Park Expedition for assistance with fieldwork and to the staff and rangers of the Kenya Wildlife Service for extensive support. Dr K. Bock kindly commented on an earlier draft. Thanks are also due to all sponsors of the project which was also part-funded by the UK Overseas Development Administration.

\section{LITERATURE CITED}

Alcala, A. C. (1988). Effects of marine reserves on coral fish abundances and yields of Philippine coral reefs. Ambio 17 : $194-199$

Alcala, A. C., Russ, G. R. (1990). A direct test of the effects of protective management on abundance and yield of tropical marine resources. J. Cons. int. Explor. Mer 47: $40-47$

Ayling, A. M., Ayling, A. L. (1986). Coral trout survey data: raw data sheets and abundance summaries from all surveys of coral trout species (Plectromus spp.) carried out by Sea Research for the Great Barrier Reef Marine Park Authority between February 1983 and July 1986. Report to the Great Barner Reef Marine Park Authority, Townsville

Beinssen, K. (1989). Results of the Boult Reef replenishment area study. Dept of Conservation, Parks Wildl, Queensland National Parks Wildl. Service, Brisbane

Bell, J. D., Craik, G. J. S., Pollard, D. A., Russel, B. C. (1985) Estimating length frequency distributions of large reef fish under water. Coral Reefs 4: 41-44

Bohnsack, J. A. (1990). The potential of marine fishery reserves for reef fish management in the U.S. southern Atlantic. NOAA tech. Memo NMFS-SEFC-261, Miami

Bohnsack, J. A., Sutherland, D. L., Harper, D. E., McClellan, D. B., Hulsbeck, M. W., Holt, C. M. (1989). The effects of fish trap mesh size on reef fish catch off southeastern Florida. Mar. Fish. Rev. 51: 36-46

Brock, R. E. (1982). A critique of the visual census method for assessing coral reef fish populations. Bull. mar. Sci. 32: $269-276$

Bryceson, I., De Souza, T F., Jehangeer, I., Ngoile, M. A. K., Wynter, P. (1990). State of the marine environment in the Eastern African Region. UNEP Regional Seas Reports and Studies No. 113, United Nations Environment Programme, Nairobi

Buxton, C. D., Smale, M. J. (1989). Abundance and distribution patterns of three temperate marine reef fish (Teleostei: Sparidae) in exploited and unexploited areas off the Southern Cape coast. J. appl. Ecol. 26: 441-451

Clark, J. R., Causey, B., Bohnsack, J. A. (1989). Benefits from coral reef protection: Looe Key Reef, Florida. In: Magoon, O. T., Converse, H., Miner, D., Tobin, L. T., Clark, D. (eds.) Coastal zone 1989: Proceedings of the sixth Symp. on coastal and ocean management, Charleston, 11-14 July 1989. American Society of Civil Engineers, New York p. 3076-3086

Coppola, S. R. (1982). Aerial frame survey along the coast of Kenya (artisanal sector). Food and Agriculture Organisation of the United Nations, Rome

Craik, W. (1979). Survey identifies trends in reef fish catches. Aust. Fish. 1979: 29-32

Ferry, R. E., Kohler, C. C. (1987). Effects of trap fishing on fish populations inhabiting a fringing coral reef. N. Am. Fish. Manage. 7: $580-588$

Gaudian, G., Medley, P. A. H., Ormond, R. F. G. (in press). A study of the size, immigration and spatial distribution of a coral reef fish stock. Coral Reefs

Greene, L. E., Alevizon, W. S. (1989). Comparative accuracies of visual assessment methods for coral reef fishes. Bull. mar. Sci. 44: 899-912

Goeden, G. B. (1982). Intensive fishing and a keystone predator species: ingredients for community instability. Biol. Cons. 22: 273-281

Grigg, R. W., Polvina, J. J., Atkinson, M. J. (1984). Model of a coral reef ecosystem. InI. Resource limitation, community regulation, fisheries yield and resource management. Coral Reefs 2: 23-27

Hay, M. E. (1984). Patterns of fish and urchin grazing on Caribbean coral reefs: are previous results typical? Ecology 65 : $446-454$

Hurlbert, S. H. (1984). Pseudoreplication and the design of ecological experiments. Ecol. Monogr. 54:187-211

Johannes, R. E. (1978). The productive strategies of coastal marine fishes in the tropics. Environ. Biol. Fish. 3: 65-84

Koslow, J. A., Hanley, F., Wicklund, R. (1988). Effects of fishing on reef fish communities at Pedro Bank and Port Royal Cays, Jamaica. Mar. Ecol. Prog. Ser. 43: 201-212

Lock, J. M. (1986). Effects of fishing pressure on the fish resources of the Port Moresby barrier and fringing reefs. Tech. Rep. 86/3, Dept of Primary Industry, Fisheries Division, Port Moresby

Loubens, G. (1980). Biologie de quelques espèces de poissons du lagon néo-calédonien. III Croissance. Cahiers de l'Indopacifique 2: 101-153

McClanahan, T R., Muthiga, N. A. (1988). Changes in Kenyan coral reef community structure and function due to exploitation. Hydrobiologia 166: 269-276

McClanahan, T. R., Muthiga, N. A., Obura, D., Mutere, J., Mwachinega, S. (1992). Status of Kenyan coral reef lagoons. Wildlife Conservation International Coral Reef Conservation Project, Mombasa, Kenya

McClanahan, T. R., Shafir, S. H. (1990). Causes and consequences of sea urchin abundance and diversity in Kenyan coral reef lagoons. Oecologia 83: 362-370

Messiha-Hanna, R., Ormond, R. F. G. (1982). Oil pollution, urchin erosion and coral reef deterioration in the Egyptian Red Sea. Iraqi J. mar. Sci. 1: 35-57

Munro, J. L., Williams, D. McB. (1985). Assessment and management of coral reef fisheries: biological, environmental and socioeconomic aspects. Proc. 5th int. coral Reef Congr. 4: $544-578$

Olindo, P. M., Asava, W. W. (1975). The establishment of marine parks in Kenya. In: Promotion of the establishment of marine parks and reserves in the Northern Indian Ocean including the Red Sea and the Persian Gulf. Papers and proceedings of regional meeting, Tehran, Iran, 6-10 March 1975. International Union for the Conservation of Nature, Switzerland

Ormond, R. F. G., Bradbury, R., Bainbridge, S., Fabricius, K., Keesing, J., De Vantier, L, Medley, P., Steven, A. (1991). 
Test of a model of regulation of crown-of-thorns starfish by fish predators. In: Bradbury, R. (ed.) Acanthaster and the coral reef: a theoretical perspective. Lecture Notes Biomath. 88: 189-207

Ormond, R. F. G. Campbell, A. C. (1971). Observations on Acanthaster planci and other coral echinoderms in the Sudanese Red Sea. Symp. Zool. Soc. Lond. 28: 433-454

Pauley, D. (1979). Theory and management of tropical multispecies stocks: a review with emphasis on the South Eastern Asian demersal fisheries. ICLARM Stud. Rev. 1: $1-35$

Polovina, J. J. (1984). Model of a coral reef ecosystem. 1. The ECOPATH model and its application to French Frigate Shoals. Coral Reefs 3: 1-11

Randall, J. E., Bishop, B. P. (1967). Food habits of reef fishes of the West Indies. Stud. Trop. Oceanogr. (Miami) 5:665-847

Reese, E. S. (1981). Predation on corals by fishes of the family Chaetodontidae: implications for conservation management of coral reef ecosystems. Bull. mar. Sci. 31: 594-604

Ricker, W. E. (1969)., Food from the sea. In: Cloud, P. (chairman) Resources and man, a study and recommendations. Report to the committee on resources and man. U.S natl. Acad. Sci. Freeman, San Francisco, p. 87-108

Roberts, C. M., Ormond, R. F. G., Shepherd, A. R. D. (1988). The usefulness of butterflyfishes as environmental indicators on coral reefs. Proc. 6th int. coral Reef Symp. 2: $331-336$

Roberts, C. M., Polunin, N. V. C. (1991). Are marine reserves effective in management of reef fisheries? Rev. Fish Biol. Fish. 1: $65-91$

Russ, G. (1984). Effects of fishing and protective management on coral reets at four locations in the Visayas, Philippines. Phase 2 UNEP-NRMC Coral Reef Monitoring Project, Silliman University Marine Lab., Dumaguete City, Philippines

This article was submitted to the editor
Russ, G. (1985). Effects of protective management on coral reef fishes in the central Philippines. Proc. 5th int. coral Reef Congr. 4: 219-224

Russ, G. R., Alcala, A. C. (1989). Effects of intense fishing pressure on an assemblage of coral reef fishes. Mar. Ecol. Prog. Ser. 56: 13-27

Sale, P. F., Sharp, B. J. (1983). Correction for bias in visual transect censuses of coral reef fishes. Coral Reefs 2: 37-42

Samoilys, M. A. (1988). Abundance and species nchness of coral reef fish on the Kenyan coast: the effects of protective management and fishing. Proc. 6 th int. coral Reef Symp. 2: 261-266

Shapiro, D. Y (1987). Reproduction in groupers. In: Polovina, J. J., Ralston, S. (eds.) Tropical snappers and groupers: biology and fisheries management. Westview Press, Boulder, p. 295-327

Sparre, P., Ursin, E., Venema, S. C. (1989). Introduction to tropical fish stock assessment. Part 1 -manual. FAO Fisheries Tech. Pap. 306/1

Stevenson, S. (1993). Corals and reefs. Kenya Shimoni Marine Park Expedition 1992 report on the distribution of habitats and species of Kisite Marine National Reserve, Part 1. Tropical Marine Research Unit, York, England

Thresher, R. E., Gunn, J. S. (1986). Comparative analysis of visual census techniques for highly mobile reef associated piscivores (Carangidae). Environ. Biol. Fish. 17: 93-116

Ursin, E. (1982). Stability and variability in the marine ecosystem. Dana 2: 51-67

Williams, D. M., Hatcher, A. I. (1983). Structure of fish communities on outer slopes of inshore mid-shelf and outer shelf reefs of the Great Barrier Reef. Mar. Ecol. Prog. Ser 10: $239-250$

Wright, A., Richards, A. H. (1985). A. multispecies fishery associated with coral reefs in the Tigak Islands, Papua New Guinea. Asian mar. Biol. 2: 69-84

Manuscript first received: August 5, 1993

Revised version accepted: January 14, 1994 